\title{
Nierówności dochodowe i majątkowe w Polsce: nowe wyniki wykorzystujące dane pozaankietowe
}

\author{
Michat Brzeziński Katarzyna Sałach \\ Wydział Nauk Ekonomicznych \\ Uniwersytet Warszawski
}

\begin{abstract}
Streszczenie
Praca podejmuje problem oszacowania poprawnych poziomów nierówności dochodowych i majątkowych w Polsce przy wykorzystaniu danych ankietowych, podatkowych oraz danych pochodzących z list najbogatszych Polaków. Wykorzystujemy metody oparte na imputacji najwyższych wartości dochodów i majątków na podstawie modelu Pareta dopasowanego do połączonych danych ankietowych i pozaankietowych. Wyniki wskazują, że faktyczne nierówności dochodowe i majątkowe w Polsce są znacząco wyższe, niż pokazują to oficjalne oszacowania oparte wyłącznie na danych ankietowych. W szczególności faktyczny poziom współczynnika Giniego dla rozkładu dochodów w 2015 roku był około 25\% wyższy niż obliczony na podstawie danych ankietowych. Z kolei skorygowany współczynnik Giniego dla majątków netto gospodarstw domowych był w roku 2014 wyższy o około 9\% niż jego odpowiednik uzyskany wyłącznie na podstawie danych ankietowych. Nasze rezultaty sugerują, że standardowy pogląd, zgodnie z którym nierówności dochodowe w Polsce są obecnie relatywnie umiarkowane, a transformacja gospodarcza w Polsce była procesem relatywnie egalitarnym, powinien być zrewidowany.
\end{abstract}

\section{Summary}

This paper studies the problem of estimating corrected levels of income and wealth inequality in Poland using data from household surveys, tax sources and rich lists. We impute the highest income and wealth observations from the Pareto model fitted to the joined survey and non-survey data. Our results show that real economic inequalities in Poland are substantially higher than surveybased estimates suggest. In particular, the corrected Gini coefficient for income distribution in 2015 is about $25 \%$ higher than a survey-based estimate. For household net wealth distribution, the corrected estimate is $9 \%$ higher than its survey-based counterpart. Our results imply that the standard view suggesting that income inequality in Poland is nowadays relatively moderate and that the post-socialist transformation in Poland was a relatively egalitarian process should be revised.

Słowa kluczowe: nierówności dochodowe, nierówności majątkowe, dane podatkowe, dane ankietowe, rozkład Pareta, Gini, Polska

Podziękowania

Niektóre badania przedstawione w niniejszym artykule (Brzeziński, Myck i Najsztub 2019, Brzeziński, Sałach i Wroński 2019; Sałach i Brzeziński 2019a, b) zostały sfinansowane przez Narodowe Centrum Nauki poprzez grant numer 2017/25/B/HS4/01360. 


\section{Wprowadzenie}

W ostatnich latach zagadnienie nierówności ekonomicznych, w tym przede wszystkim nierówności dochodowych i majątkowych, stało się jednym z najważniejszych problemów badawczych w ekonomii. Liczne badania pokazują, że w wielu krajach wysoko rozwiniętych nierówności ekonomiczne wzrosły znacząco w okresie ostatnich 3-4 dekad (Chancel 2019). Wzrosły one również wyraźnie w krajach post-socjalistycznych, choć dla tych krajów dane o dochodach i majątkach ludności są gorszej jakości. Tradycyjnie do pomiaru nierówności ekonomicznych wykorzystywano dane dochodowe lub majątkowe pochodzące z reprezentatywnych badań ankietowych, takich jak Badanie Budżetów Gospodarstw Domowych (BBGD) GUS dla Polski. Jednak w wielu badaniach pokazano, że oszacowania poziomów i trendów nierówności ekonomicznych oparte wyłącznie na danych ankietowych są silnie niedoszacowane (zob. np. Jenkins 2017, Bartels i Metzing 2019, Bach i in 2019). Wynika to przede wszystkim z faktu, że najwyższe dochody i majątki nie są wystarczająco dobrze reprezentowane w danych ankietowych - osoby osiągające najwyższe dochody lub mające najwyższe majątki częściej odmawiają udziału w badaniach ankietowych lub nie deklarują pełnych wartości swoich dochodów czy majątków. W niniejszym artykule przedstawiamy krótki przegląd ostatnich badań empirycznych dotyczących nierówności ekonomicznych (dochodowych i majątkowych) w Polsce, przy których obliczeniu wykorzystano nie tylko dane ankietowe,

ale również dane podatkowe oraz informacje pochodzące z list najbogatszych Polaków (Brzeziński, Myck i Najsztub 2019, Brzeziński, Sałach i Wroński 2019; Sałach i Brzeziński 2019a, b). Wyniki uzyskane w tych pracach pokazują, że faktyczne poziomy nierówności ekonomicznych (dochodowych i majątkowych) w Polsce są prawdopodobnie znacząco wyższe, niż poziomy oficjalne, obliczone przy użyciu tylko danych ankietowych. Nowe oszacowania poziomów nierówności, wykorzystujące dane pozaankietowe, stawiają w nowym świetle standardowy pogląd, zgodnie z którym Polska jest krajem relatywnie egalitarnym. Pokazują również, że ocena polskiej transformacji post-socjalistycznej jako procesu, który nie doprowadził do powstania dużych nierówności ekonomicznych, powinna być zrewidowana.

\section{Skorygowane miary nierówności dochodowych dla Polski}

W swoim przełomowym artykule Bukowski i Novokmet (2019) po raz pierwszy oszacowali miary nierówności dla Polski przy wykorzystaniu danych pozaankietowych. Opierając się na połączo- 
nych danych ankietowych, podatkowych (z corocznych informacji Ministerstwa Finansów o rozliczeniu podatku PIT) oraz danych pochodzących z rachunków narodowych obliczyli oni miary nierówności (głównie udziały różnych grup kwantylowych) w kategoriach dochodów do opodatkowania lub dochodu narodowego przed opodatkowaniem. Ich wyniki pokazują, że faktyczny wzrost nierówności dochodowych w Polsce w okresie po 1989 roku był znacznie większy niż sugerują to dane ankietowe BBGD GUS. Przykładowo, udział dochodów 10\% osób osiągających najwyższe dochody w całkowitym dochodzie przed opodatkowaniem wynosił w roku 1992 około $25 \%$, podczas gdy dla danych ankietowych analogiczna miara przyjmowała wartość około $23 \%$. W roku 2015 miary te przyjmowały już odpowiednio wartości 35\% i 26\%. Podobnie wysoki lub nawet wyższy poziom nierówności dochodowych w Polsce w roku 2016 uzyskali Blanchet, Chanel i Gethin (2019) również wykorzystując połączone dane ankietowe, podatkowe oraz makroekonomiczne. Bukowski i Novokmet (2019) wskazują, że nierówności dochodowe wzrosły w Polsce szczególnie szybko w okresie 2004-2008, co wynikało z gwałtownego przyrostu wysokich dochodów w grupie osób prowadzących działalność gospodarczą. Autorzy sugerują, że wzrost udziału kapitału w dochodzie narodowym Polski po 2004 roku dokonał się głównie w wyniku działania różnych mechanizmów globalizacyjnych, które mogły sprzyjać bardziej kapitałowi niż pracy.

Brzeziński, Myck i Najsztub (2019) wykorzystują podatkowo skorygowane udziały dochodowe górnych grup kwantylowych pochodzące z pracy Bukowskiego i Novokmeta (2019) do obliczenia skorygowanych miar nierówności dla Polski w kategoriach standardowych miar dobrobytu indywidualnego - ekwiwalentnych dochodów po opodatkowaniu. W badaniu tym wykorzystano metody kalibracji wag BBGD (Myck i Najsztub 2015), tak aby prawidłowo odzwierciedlały one polską populację względem cech demograficznych (wagi populacyjne), a także dodatkowo by dobrze reprezentowały strukturę podatników PIT według skali podatkowej (wagi podatkowe). Najwyższe dochody zostały imputowane do danych BBGD według metodologii Bartels i Metzing (2019) na podstawie modelu rozkładu dochodów Pareta, którego parametry zostały obliczone na podstawie miar nierówności oszacowanych przez Bukowskiego i Novokmeta (2019). W porównaniu do pracy Bukowskiego i Novokmeta (2019) wyniki w pracy Brzezińskiego, Mycka i Najsztuba (2019) są przedstawione w kategoriach dochodowych (dochód ekwiwalentny po opodatkowaniu) bezpośrednio porównywalnych z oficjalnymi oszacowaniami miar nierówności, które publikują m.in. GUS i Eurostat. Główne wyniki tego ostatniego badania są przedstawione na rys. 1. 
Rys. 1. Indeks Giniego dla Polski w latach 1994-2015: nieskorygowane a skorygowane oszacowania (wertykalne linie pokazują 95\% przedziały ufności obliczone przy użyciu metody bootstrap)

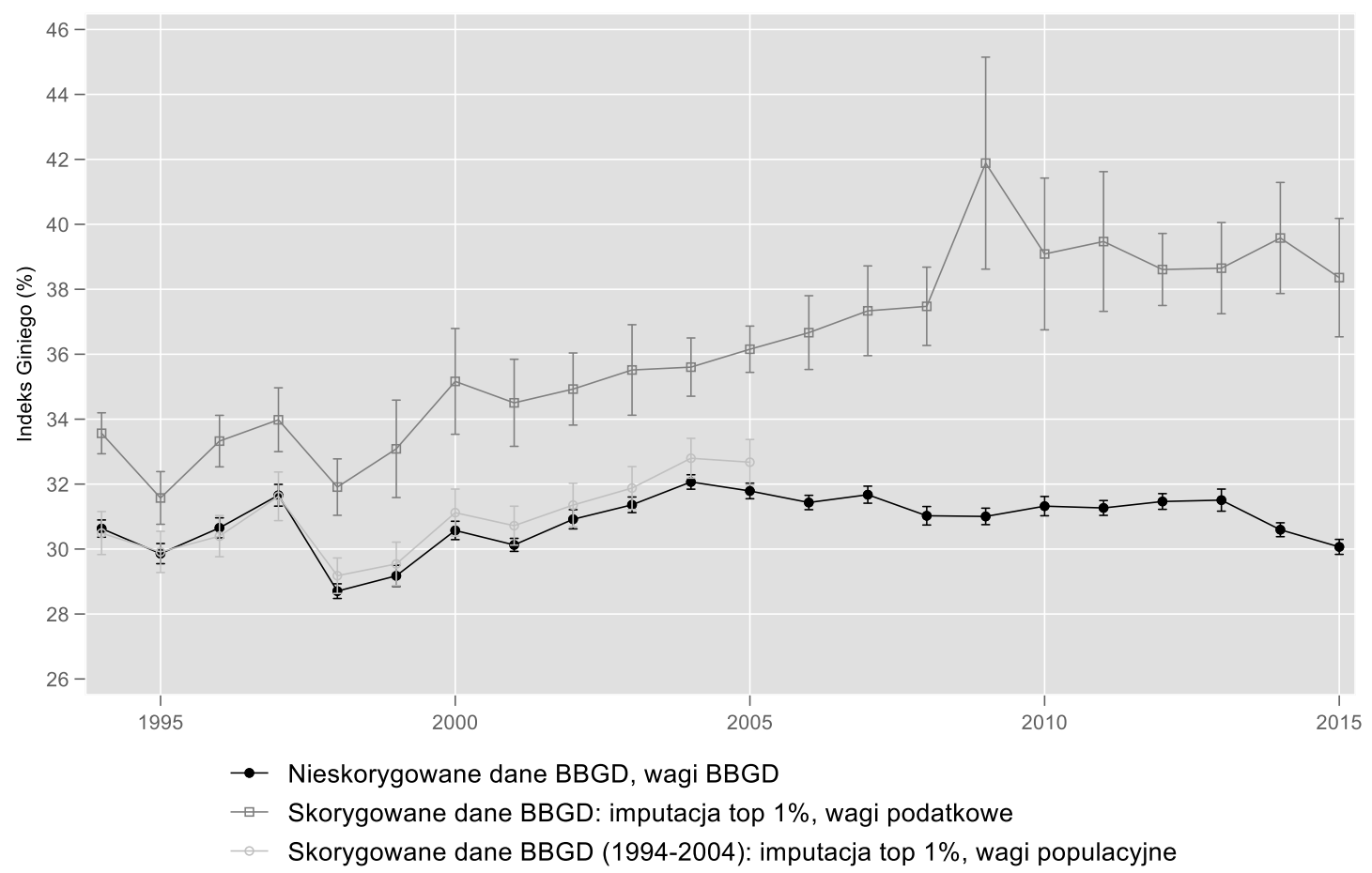

Źródło: Brzeziński i in. (2019).

Nieskorygowane dane BBGD wskazują, że w okresie 1994-2015 nierówności dochodowe w Polsce mierzone indeksem Giniego praktycznie nie zmieniły się. Skorygowane serie danych pokazują, że indeks Giniego wzrósł z poziomu 0,3-0,34 w roku 1994 do poziomu 0,38 w roku 2015. W roku 2015 był on zatem około 25\% wyższy, niż wskazywały to oszacowania oparte na danych ankietowych. Według skorygowanych danych indeks Giniego wzrósł w okresie 1994-2015 w przedziale od 14 do 26\% (w zależności od przyjętego wariantu analizy). Porównując skorygowane oszacowania współczynnika Giniego dla Polski i innych krajów, dla których istnieją analogiczne rezultaty, możemy stwierdzić, że w Polsce już na początku lat 90. nierówności dochodowe były relatywnie wysokie. W roku 2015 Polska stała się jednak jednym z najbardziej nierównych krajów w Europie poza Rosją. W okresie transformacji gospodarczej największe korzyści uzyskały osoby uzyskujące najwyższe dochody. Dochody tych osób rosły również w wyniku niektórych reform systemu podatkowego. Progresywność systemu podatków od dochodów osobistych zmalała o 40\% w okresie 1999-2015. Tym samym polski system PIT stał się w 2015 roku jednym z najmniej progresywnych 
w Europie. Korekta indeksu Giniego dla Polski oszacowana w omawianym artykule jest 2-3-krotnie większa niż korekty wykonane według analogicznych metodologii dla innych państw europejskich (głównie zachodnich). Wynika to z faktu, że większość zachodnich państw europejskich w mniejszym stopniu niż Polska polega na danych ankietowych jako podstawowym źródle informacji o rozkładzie dochodów. Wiele państw wykorzystuje bezpośrednio dane administracyjne (pochodzące z zeznań podatkowych lub z systemu ubezpieczeń społecznych).

\section{Skorygowane miary nierówności majątkowych}

W artykule Brzezińskiego, Sałach i Wrońskiego (2019) badany jest problem niedoszacowania miar nierówności majątkowych w krajach Europy Środkowo-Wschodniej, obliczonych przy wykorzystaniu danych ankietowych z badania Household Finance and Consumption Survey (HFCS). W celu skorygowania tych oszacowań wykorzystane zostały metody imputacji oparte na dopasowywaniu modelu Pareta do połączonych danych HFCS oraz danych o najwyższych majątkach pochodzących z list najbogatszych mieszkańców krajów naszego regionu. W przypadku Polski wykorzystane zostały dane z listy 100 najbogatszych Polaków magazynu Forbes. Główne wyniki pracy pokazuje rys. 2 .

Rys. 2. Wzrost wartości współczynnika Giniego dla majątku netto gospodarstw domowych w roku 2014 wynikający z imputacji najwyższych majątków (Polska i inne kraje Europy ŚrodkowoWschodniej oraz Francja, Hiszpania i Niemcy)

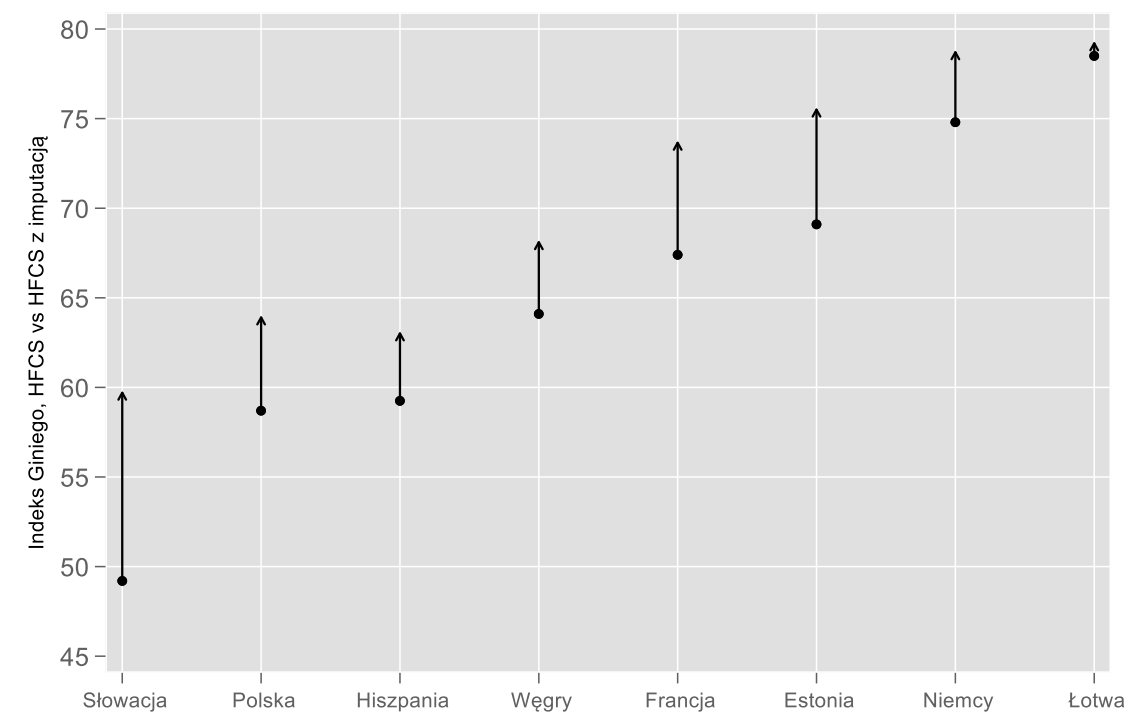

Źródło: Brzeziński, Sałach i Wroński (2019) dla krajów Europy Środkowo-Wschodniej oraz Bach $\mathrm{i}$ in. (2019) dla pozostałych krajów. 
Skorygowanie danych ankietowych o majątkach netto gospodarstw domowych prowadzi do wzrostu współczynnika Giniego dla Polski z 0,59 do 0,64, zaś udział majątków 1\% najbogatszych w całkowitym majątku Polaków niemal podwaja się z 12,1\% do 20,3\%. Oceniając nierówności majątkowe przy użyciu tej ostatniej miary możemy stwierdzić, że są one na podobnym poziomie jak w Hiszpanii i nieco tylko niższe niż we Francji. Wynik ten jest zaskakujący, jako że standardowy pogląd głosi, że nierówności majątkowe są w Polsce raczej niskie, gdyż proces kumulacji majątków charakterystyczny dla gospodarek rynkowych rozpoczął się ledwie trzy dekady temu. Brzeziński, Sałach i Wroński (2019) podają różne możliwe wyjaśnienia faktu, że nierówności majątkowe w Polsce nie są tak niskie jak sugerowały wyniki oparte wyłącznie na danych ankietowych.

Zagadnienie nierówności majątkowych w Polsce jest również badane w pracach Sałach i Brzezińskiego (2019a, b). W pierwszej z tych prac wykorzystujemy metody dekompozycji mikroekonomicznych, by wskazać determinanty znacznych różnic (zob. rys. 2) w poziomie nierówności majątkowych w krajach Europy Środkowo-Wschodniej (Sałach i Brzeziński 2019a). Nasze wyniki wskazują, między innymi, że niższy poziom nierówności majątkowych na Słowacji w porównaniu z Polską wynika w około 30\% z wyższego na Słowacji odsetka osób, które posiadają mieszkania własnościowe. W drugim artykule (Sałach i Brzeziński 2019b) analizujemy trendy w majątkach najbogatszych Polaków w okresie 2002-2018 używając danych z corocznych list publikowanych przez czasopisma Forbes i Wprost. Choć dane pochodzące z list najbogatszych osób charakteryzują się pewną niedokładnością, to jest to jedyne źródło informujące o najwyższych wartościach majątków w większości krajów. Są one powszechnie wykorzystywane w badaniach ekonomicznych nad nierównościami majątkowymi (zob. np. Klass i in. 2006, Piketty 2014). Nasze rezultaty pokazują, że realne średnie majątki stu najbogatszych Polaków rosły w okresie 2002-2018 średnio w tempie 4\% rocznie. W tym samym czasie PKB per capita rosło średnio w tempie 3,8\%, zaś średnie dochody gospodarstw domowych powiększały się średnio o 3,5\%. Tym samym majątki najbogatszych rosły nieco tylko szybciej niż średnie dochody Polaków. Majątki najbogatszych Polaków zdają się rosnąć nieco wolniej niż majątki najbogatszych ludzi na świecie. Według danych z Forbes World Billionaires tempo wzrostu realnych majątków netto najbogatszych ludzi na świecie w okresie 1987-2017 wynosiło 6,4\%, zaś dla Chin, Europy i Stanów Zjednoczonych było równe średnio 7,8\%. Z drugiej strony stopa wzrostu sumy majątków 40 najbogatszych osób w Polsce wynosiła w okresie 2010-2018 aż 8,1\% i była znacząco wyższa niż w Rosji czy Niemczech. 
Niestety z powodu braku szeregów czasowych opisujących zmiany majątków całej populacji nie jest możliwe porównanie tempa wzrostu majątków najbogatszych ze stopą wzrostu średniego majątku Polaków. Z podobnego powodu nie można przedstawić szeregów czasowych dla standardowych miar nierówności majątkowych w Polsce. W związku z tym trendy w nierównościach majątkowych w Polsce można przedstawić jedynie za pomocą przybliżonej miary jaką jest stosunek sumy majątków stu najbogatszych Polaków oraz polskiego PKB. Wyniki pokazują (rys. 3), że tak rozumiana nierówność majątkowa jest w Polsce z grubsza stała w czasie. Poza wzrostem w przedkryzysowym okresie 2006-2008, oszacowania naszej miary oscylują wokół 6-7\%. Tymczasem analogiczna miara dla USA pokazuje szybki wzrost po 2009 roku z ok. $6 \%$ do ponad $10 \%$.

Rys. 3. Suma majątków stu (Polska) lub dwustu (USA) najbogatszych osób w stosunku do PKB kraju zamieszkania

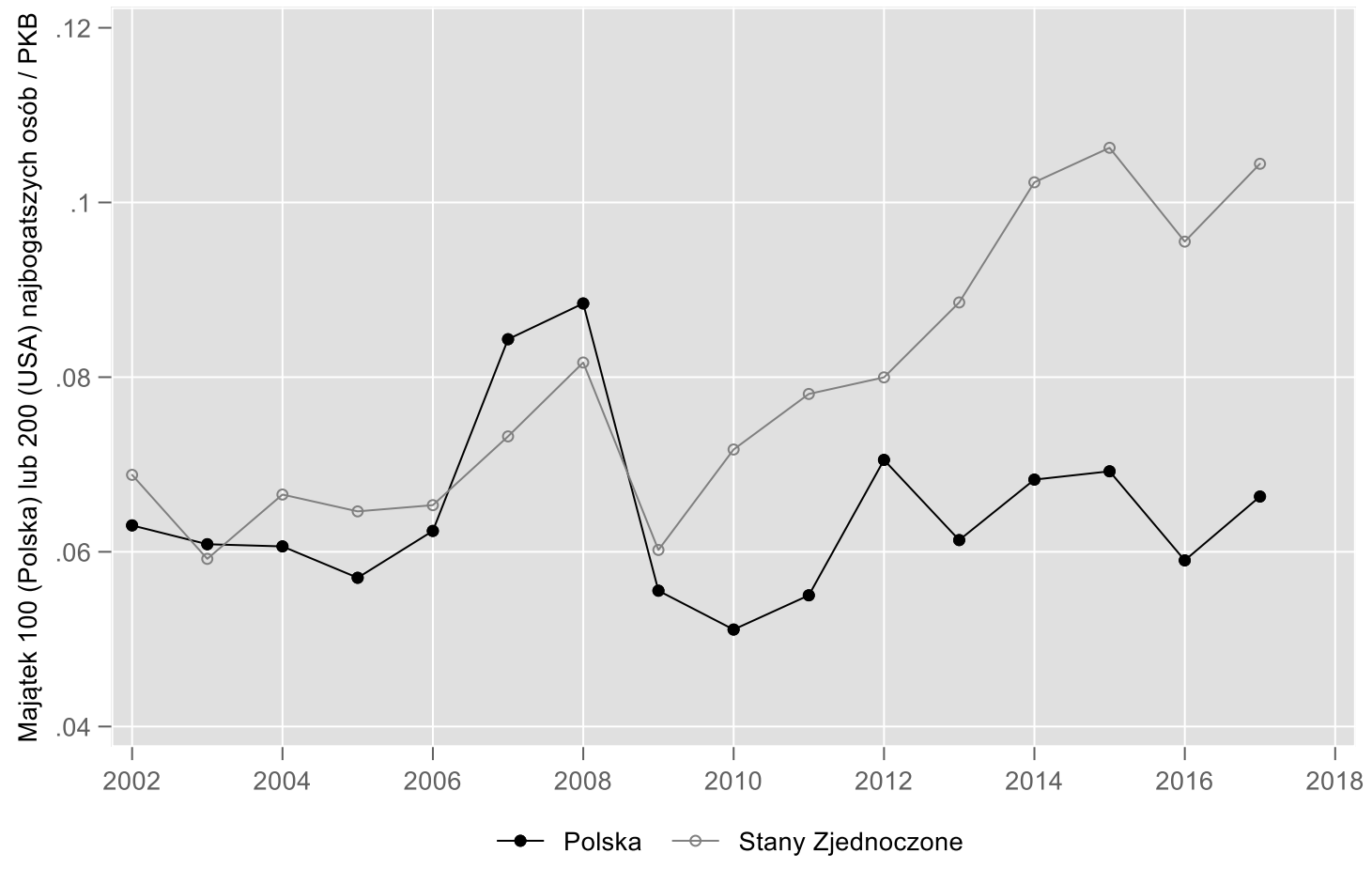

Źródło: Sałach i Brzeziński (2019b).

\section{Konkluzje}


W niniejszym artykule zaprezentowano krótko najnowsze badania nad nierównościami dochodowymi i majątkowymi w Polsce, których celem jest rozwiązanie problemu niewystarczającego pokrycia najwyższych dochodów i majątków w zbiorach danych ankietowych. Badania te wykorzystują techniki przeważania danych ankietowych oraz imputacji najwyższych obserwacji przy wykorzystaniu zewnętrznych zbiorów danych (takich jak dane podatkowe lub dane z list najbogatszych obywateli). Podstawowy wniosek z tych badań mówi, że skorygowane oszacowania nierówności ekonomiczne są znacząco wyższe w stosunku do tych opartych wyłącznie na danych ankietowych. Korekta ze względu na brakujące w danych ankietowych najwyższe obserwacje podwyższa współczynnik Giniego o 25\% w przypadku rozkładu dochodów i o 9\% dla rozkładu majątku. Ponieważ dla rozkładu dochodów korekta tego typu jest dla większości krajów europejskich mniejsza niż dla Polski, wydaje się, iż standardowy pogląd, według którego nierówności dochodowe w Polsce są na średnim poziomie europejskim, powinien zostać zrewidowany. $Z$ dużym prawdopodobieństwem można przyjąć, że Polska sytuuje się obecnie raczej wśród najbardziej nierównych dochodowo krajów europejskich, a transformacja post-socjalistyczna była w naszym kraju procesem znacznie bardziej rozwarstwiającym, niż przyznawano to do tej pory. Wydaje się również, że instytucje odpowiedzialne za oficjalne oszacowania miar nierówności ekonomicznych w Polsce powinny w znacznie szerszym zakresie korzystać z danych pozaankietowych.

\section{Bibliografia}

Bach, S., Thiemann, A., \& Zucco, A. (2019). Looking for the missing rich: Tracing the top tail of the wealth distribution. International Tax and Public Finance, 26(6), 1234-1258.

Bartels, C., \& Metzing, M. (2019). An integrated approach for a top-corrected income distribution. The Journal of Economic Inequality, 17(2), 125-143.

Blanchet T., Chancel L., Gethin A. (2019), How unequal is Europe? Evidence from distributional national accounts. WID.world Working Paper 2019/6.

Brzeziński M., Myck M., Najsztub M. (2019), Reevaluating Distributional Consequences of the Transition to Market Economy in Poland: New Results from Combined Household Survey and Tax Return Data. IZA DP No. 12734.

Brzezinski M., Sałach K., Wroński M. (2019), Wealth inequality in Central and Eastern Europe: evidence from joined household survey and rich lists' data. Working Papers 2019-09, Faculty of Economic Sciences, University of Warsaw.

Bukowski P., Novokmet F. (2019), Between Communism and Capitalism: Long-Term Inequality in Poland, 1892-2015. CEP Discussion Paper No 1628 June 2019.

Chancel L. (2019), Ten facts about inequality in advanced economies. Forthcoming in "Combating Inequality: Rethinking Policies to Reduce Inequality in Advanced Economies" (eds. O. Blanchard, D. Rodrik), MIT Press, 2020. 
Jenkins, S. P. (2017). Pareto models, top incomes and recent trends in UK income inequality. Economica, 84(334), 261-289.

Klass O. S., Biham O., Levy M., Malcai O., Solomon S. (2006), The Forbes 400 and the Pareto wealth distribution. Economics Letters, 90(2), 290-295.

Myck M., Najsztub, M. (2015), Data and model cross-validation to improve accuracy of mi-crosimulation results: estimates for the Polish Household Budget Survey. International Journal of Microsimulation, 8(1), 33-66.

Piketty T. (2014), Capital in the Twenty-First Century, Cambridge, Massachusetts, Th e Belknap Press of Harvard University Press.

Sałach K., Brzeziński, M. (2019a), Differences in Wealth and Wealth Inequality among the CEE Countries. Artykuł zaprezentowany na konferencji IARIW-HSE, Moskwa.

Sałach K., Brzeziński, M. (2019b), Do the super-rich benefit from political connections? Evidence from Poland. Artykuł zaprezentowany na konferencji ECINEQ 2019, Paryż. 